\title{
Liver cancers and other hepatic disease from the Adult/Adolescent Spectrum of HIV-related Diseases (ASD) Project
}

\author{
David Aboulafia ${ }^{1,2^{*}}$, Susan Buskin ${ }^{3,4}$, Elizabeth Barash ${ }^{3}$, John Scott ${ }^{5}$, Robert Wood ${ }^{3,6}$ \\ From $12^{\text {th }}$ International Conference on Malignancies in AIDS and Other Acquired Immunodeficiencies \\ (ICMAOI) \\ Bethesda, MD, USA. 26-27 April, 2010
}

\section{Background}

As individuals with HIV infection live longer due to highly active antiretroviral therapy (HAART), co-morbid conditions and infections, including liver cancers and viral hepatitis, warrant increased attention and action.

\section{Materials and methods}

The multisite ASD Project followed 29,491 HIV-infected individuals receiving medical care in 11 U.S. metropoli$\tan$ areas for an average of 2.4 years and a total of 69,487 person-years. ASD collected data on the presentation, treatment, and outcomes related to HIV infection, including viral hepatitis screening and liver-specific complications including hepatic neoplasms. Data were restricted to the HAART era, 1998-2004.

\section{Results}

There were 25 participants with liver malignancies in the ASD cohort corresponding to a rate of 8.5 cancers/ 10,000 people living with HIV. Twenty two (88\%) participants died and the remaining 3 were lost to followup. Fifteen $(60 \%)$ of the 25 had hepatocellular carcinoma; 6 had metastatic adenocarcinoma, 1 each had lymphoma, hepatoblastoma, sarcoma, and poorly differentiated carcinoma. Thirteen of 25 (52\%) individuals with liver malignancies were diagnosed with hepatitis $C$ virus (HCV) and 10 (40\%) with chronic hepatitis B virus (HBV) infection (including 2 participants with HBV and HCV co-infection). This corresponds to a relative risk of liver cancer among $\mathrm{HCV}$ and $\mathrm{HBV}$ infected individuals

\footnotetext{
*Correspondence: david.aboulafia@vmmc.org

${ }^{1}$ Department of Hematology and Oncology, Virginia Mason Medical Center, Seattle, WA, USA

Full list of author information is available at the end of the article
}

of 12.8 (95\% confidence interval $[\mathrm{CI}]=4.1-40.2)$ and 26.8 (95\% CI $=8.1-88.9$ ), respectively (relative to those without $\mathrm{HBV}$ or $\mathrm{HCV}$ diagnoses). The risk of malignancy in HIV-infected individuals with both HBV and $\mathrm{HCV}$ co-infection, relative to those with neither coinfection, was 16.8 (95\% CI = 3.1-91.8). Four individuals did not undergo HBV or HCV screening, and their viral hepatitis serostatus remained undefined. Twelve percent of liver cancer patients also had a diagnosis of cirrhosis, relative to a 1 percent prevalence of cirrhosis overall (relative risk of liver cancer for those with cirrhosis = $10.2,95 \% \mathrm{CI}=3.1-33.9)$. Incident liver disease and chronic $\mathrm{HBV}$ and $\mathrm{HCV}$ were diagnosed in $0.9,1.8$, and 4.7 per 100 person-years. HBV and HCV screening increased from fewer than $20 \%$ to over $60 \%$ during this period of observation $(\mathrm{p}<.001)$. Deaths occurred in $57 \%$ of those diagnosed with liver disease relative to $15 \%$ overall ( $\mathrm{p}<.001)$. Overall, $10 \%$ of deaths occurred among individuals with a diagnosis of liver disease.

\section{Conclusions}

Despite care guidelines promoting screening for HBV and $\mathrm{HCV}$, screening was not universally conducted or, if conducted, not documented. Due to elevated risks of liver cancer and other liver diseases, HCV and HBV screening and treatment of viral hepatitis among HIV-infected individuals should be a priority in the HAART era.

\section{Acknowledgements}

This article has been published as part of Infectious Agents and Cancer Volume 5 Supplement 1, 2010: Proceedings of the $12^{\text {th }}$ International Conference on Malignancies in AIDS and Other Acquired Immunodeficiencies (ICMAOI). The full contents of the supplement are available online at http://www.biomedcentral.com/1750-9378/5?issue=S1. 


\section{Author details}

'Department of Hematology and Oncology, Virginia Mason Medical Center, Seattle, WA, USA. 'Division of Hematology, University of Washington, Seattle, WA, USA. ${ }^{3}$ Public Health, Seattle and King County, WA, USA. ${ }^{4}$ Department of Epidemiology, University of Washington, Seattle, WA, USA. ${ }^{5}$ Department of Gastroenterology, University of Washington, Seattle, WA, USA. ${ }^{6}$ Department of Infectious Disease, University of Washington, Seattle, WA, USA.

Published: 11 October 2010

doi:10.1186/1750-9378-5-S1-A51

Cite this article as: Aboulafia et al: Liver cancers and other hepatic

disease from the Adult/Adolescent Spectrum of HIV-related Diseases

(ASD) Project. Infectious Agents and Cancer 2010 5(Suppl 1):A51.

Submit your next manuscript to BioMed Central and take full advantage of:

- Convenient online submission

- Thorough peer review

- No space constraints or color figure charges

- Immediate publication on acceptance

- Inclusion in PubMed, CAS, Scopus and Google Scholar

- Research which is freely available for redistribution

Submit your manuscript at www.biomedcentral.com/submit 